\title{
Film Rating and Its Current Challenges in Malaysia and Bangladesh
}

\author{
Md. Zahidul Islam, Md. Mashiur Rahman
}

\begin{abstract}
Film rating is designed to categories film with regard to its suitability for audiences in term of issues such as sex, violence, substance abuse, profanity or other types of mature content. Ratings typically carry age recommendations. This could be regarded as a form of censorship. The main purpose of this paper is to discuss the legal framework of film rating and current challenges in implementing it. A qualitative research's method was adopted by gleaning information statutes, case law, articles and books. The research also conducted semi-structured interviews with film directors and members of the Film Censorship Board. The research found that there are some contradicting views regarding film rating between the censors and the film industry players.
\end{abstract}

Keywords: Film, Rating, Challenges, Malaysia, Bangladesh,

\section{INTRODUCTION}

Film rating is a form of censorship where restrictions are imposed on the population on what films a person could view [1]. In some instances the rating of films may result to a failure of a film producer to recoup his investment in the film. However, some view rating system as a guideline for should they or person under their care view.

Many countries adopt film rating system using names such as film classification, film certification and film categories [2]. In Britain, film rating was introduced by British Board of Film Classification in 1912. Formerly, there were no agreed rating standard and local council imposed their own restrictions and conditions. Today's voluntary movie rating system is aimed at giving parents the information they need to decide whether a film is appropriate for their family.

In America, the rating system emerged in 1968 [5], when Motion Picture Association of America (MPAA) replaced the earlier moral censorship guidelines, known as the Hays Code, with a new parent-focused rating system [4]. Hays Code provides an exhaustive list of moral to determine the "moral" of the film [3]. However, the current movie rating system is established to give leeway for film producers to make their own decision in making films and at the same films should be viewed by their family members. Films are given rating of G, PG, PG-13, R and NC-17 which guide the content of the movie. The brief guidance for the ratings respectively refer to general audiences, all ages admitted;

Dr. Md. Zahidul Isam, Civil Law Department, Ahmad Ibrahim Kulliyyah of Laws (AIKOL), International Islamic University Malaysia (IIUM). P.O. Box 10, 50728 Kuala Lumpur, Malaysia.(Email: zahidul@iium.edu.my)

Md. Mashiur Rahman, Assistant Professor, Social Work Department, Bangladesh Civil Service (General Education), Bhawal Badre Alam Government College, Gazipur, Dhaka, Bangladesh. individuals or parents or guardians to decide which films time to educate parents and helping them determining which

Revised Manuscript Received on April 19, 2019.

parental guidance suggested, some material may not be suitable for children; parents strongly cautioned, some material may be inappropriate for children under 13; restricted, children under 17 require accompanying parent or adult guardian; no one 17 and under admitted [6].

These ratings provide assistance to individuals and parents in making viewing decisions. The rating agencies are at great pains emphasis that they are not evaluating the quality of the films but rather helping individuals and particular parents in making viewing decisions [7]. These rating systems to a certain extent are also adopted in Malaysian and Bangladesh.

\section{LEGAL FRAMEWORK OF FILM RATING}

In contrast to system in some other countries, films censorship in Malaysia and Bangladesh are statutorily regulated and govern by film censorship boards. If any owner of a film wants to exhibit any film, he has to come through the film censorship boards. That means film owner has to request approval from the censorship board. Film censorship board may approve or reject any film to exhibit, to censor any part of the film, and to classify the film in accordance to suitability of age groups for viewing.

\section{A. Film Censorship Laws in Malaysia}

Film Censorship Act 2002 regulates film censorship in Malaysia. It came into force on 1st April 2002 and repealed the Film (Censorship) Act 1952. The Act establishes the Board of Censors, Appeal Committee; provides the control of film and film publicity materials; and the power relating to enforcement, seizure and arrest [8].

Such a wide power could also be seen in the power allocated to the Home Minister. If the Minister satisfied that the exhibition, display, distribution, possession, circulation or sale of any film or film publicity material would be contrary to public interest, he may prohibit the exhibition, display distribution, circulation or sale of that film by order published in the Gazette. For instance, the film The Last Communist (in Malay - Lelaki Komunis Terakhir) was banned in 2006. Amir Muhammad - the director - crafted a novel method in documenting the life of Chin Peng who was a prominent and high in the hierarchy of the Malaysian Communist Party leading - according to him - a revolution against the Japanese and British imperials. This film was first approved by Film Censorship Board but it was banned by the Ministry of Home Affair under section 26 of the Film Censorship Act 2002 which gives the Minister a discretionary power [8]. 
International Conference on Recents Advancements in Engineering and Technology (ICRAET-18) |15th and 16th March 2019|Siddhartha Institute of Technology \& Sciences, Telangana, India.

At the same time, if the Minister satisfied that the exhibition, display, distribution, possession, circulation or sale of any film or film publicity material would not be contrary to public interest or to the interest of the country, he may exempt any film or film publicity material from any provisions of this Act or regulations made under the Act.

\section{B. Film Censorship Guidelines}

Film producers in particular had criticised the working of the Censorship Board as being not business friendly because, among others, of the uncertainty and inconsistency in their decisions. To address this criticisms, the a guideline known as the Garis Panduan Lembaga Penapis Filem or Film Censorship Guideline 1993 was issued in the Malay language by the Prime Minister's Department and approved by the Cabinet on $17^{\text {th }}$ November 1993. It was amended in 2010 and known as the Garis Panduan Penapisan Filem or Film Censorship Guidelines. It could be discerned from the guideline that the need for censorship is made because of the recognition of the impact of films over the society particularly the youth and the children. The Board recognises the need for films to be allowed to be widely distributed to viewers and adults should be given the freedom to choose any content that they may wish to view as long as it is permissible and not potentially detrimental.

In determining the requirement for censorship over a film, the Board considers the theme of the film; the message conveyed by the producer; the lesson that can be gained from it; the influence of any age group; glorification of any clan, race, religion, nation or belief. A more subjective consideration and probably ill-suited for a nation that practise parliamentary democracy is for the board to consider whether the film is consistent with the aspirations of the government and the nation [9].

Consideration by the Board on the security and public order, religion, social norms, decorum and morality seems to be reasonable albeit with the caveat that the implementation also should be reasonable because the general and vague nature of such things as security and public order for instance [8].

Language used in films is also a major consideration and the Board would not tolerate cursing for instance [10]. The guideline provides list of objectionable cursing words in Malay, Chinese, English, Tamil, Hindi, Bengali and Punjabi.

Another important issue film rating has been discussed in this guideline. According to this guideline, there are three types of film. They are-

\begin{tabular}{|c|c|}
\hline Rating Symbol & Meaning \\
\hline & $\begin{array}{l}\text { There is no age } \\
\text { restriction in this category. } \\
\text { This Category is suitable for } \\
\text { viewing by all levels of } \\
\text { people. }\end{array}$ \\
\hline P13 & $\begin{array}{l}\text { There is age restriction in } \\
\text { this category. This category } \\
\text { is suitable for viewing by } \\
\text { those } 13 \text { years and above. } \\
\text { Viewers aged below } 13 \\
\text { require the guidance of their } \\
\text { parents. The film has some } \\
\text { scenes of violence or horror. }\end{array}$ \\
\hline 18 & $\begin{array}{l}\text { There is also age } \\
\text { restriction in this category. } \\
\text { This category is suitable for } \\
\text { viewing by those aged } 18 \\
\text { years and above. The film } \\
\text { has some scenes of } \\
\text { violence, horror and sex but } \\
\text { that are not excessive. }\end{array}$ \\
\hline
\end{tabular}

\section{Film Censors' and Practitioners' Views}

Film Censorship Board apart from approving the distribution of films may also request deletion of scenes and sounds. It also provides rating to it which will determine the pool of audience for the films. For instance, if a film is rated 18 after numerous cutting of objectionable scenes, the pool of potential audience is reduced. This in turn will affect the reach of the films and economic return from the screening. In one of the interviews conducted where a film director was ask about the future of film censorship in Malaysia. Film director Dr. Mahadi J Murat, noted that: "There should be a new approach. A producer or a director should have a sound knowledge about film censorship laws and should make the decision whether he is taking a lawful or unlawful shot in his film . For example, if film maker ensures that his film is from different category and there is no unpleasant thing in his film. I hope there will not be any issue for Censor board to allow it. I think it is a very good approach and Malaysia should adopt it. Categorizing movie is another aspect to make choice to approve it or not. By this there will not be any doubt whether the film will be approved or not and the producer will be aware of the film category that will not be approved by the censorship board . As a result there will be no scope to blame the censorship board for the rejection of any film. As for example, In Malaysia many people are addicted to watching porn movies through internet. There is no filtering so that teens are also watching porn movies. No censorship there, not even any categorizing. So the censorship term does not work there. This is a serous issue that should be considered by the government as well as censorship board. It is good to mix 
with the multi culture, multilingual and with multi religious views but in the world of cinema there should have filtering for the harmful films."

Film directors Amir Muhammad and Amirul Fadhli mentioned that "we have a age category 18 for audiences. The specific films are for adult people and censorship board is very strict here." They tried to mention that some category is exclusively for adults only. Therefore, adult categorising is existed already and censorship board should not be very strict for censoring adult films.

On the other hand, Mohd. Zamberi bin Abdul Aziz, chairman of the film censorship board, noted that: "I think the existed category is suitable enough for Malaysia. When we made these categories, we considered each level even the school stages. ' $U$ ' means unrestricted and it is not even harmful for primary school student. 'P13' means anyone can watch this type of film if his or her age is 13 and above. It means it will start from secondary school level. 'Category $18^{\prime}$ means anyone can watch this film if his or her is age 18 and above. It means it will start from University level." Other members of the film censorship board Mahzan bin Yusof and Abdul Manap also agreed with Abdul Ghani Bin Ibrahim. They said, "We revised film categories in 2010 and it is the most acceptable categorising." Although the members of the film censorship board of Malaysia were satisfied with the current film categories, some directors were not satisfied with it. Researcher seems that Malaysian film censorship categories are updated because it has been revised.

\section{Film Censorship Laws in Bangladesh}

Similar to Malaysia, Bangladesh employs a statutorily established Board to govern films censorship through the Film Censorship Act 1963 which was amended by the President's Order No. 41/1972. The Act requires for anyone who wants to exhibit film to take certificate from the film censorship board. The board has the power to approve or to reject distribution of films. Appeals from the decision of the Board could be made to the Government and the decision of the Government shall be final [11].

Apart from the Act, the Bangladesh Censorship of Films Rules 1977 was passed in exercise of the powers conferred by section 10 of the Censorship of Films Act 1963. The Rule provides detail of the working of the Board.

The Rule provides principles to be considered in determining applications to distribute films. The principles are: (a) the film must not portrays or not likely to decrease the moral standard of the viewer by extenuating vice or crime or by depreciating social values; (b) the film story or incident or dialogue must not offend or likely to offend sentiments of any section of the public; (c) the story or dialogue must not be harmful for children under 12 years old; (d) any element which lowering national ideology (includes absolute trust and faith almighty Allah, nationalism, democracy, socialism meaning economic and social justice) must not expect in the film.

If the film is suitable for unrestricted public exhibition with or without censorship, a "U" certificate is assigned. If the film is suitable for public exhibition only to adult (person not below eighteen years of age) with or without censorship, "A" certificate shall be assigned. Thus in contrast to Malaysia that has 3 ratings, Bangladesh has only 2 ratings [11].

\section{E. Film Censors' and Practitioners' Views}

Interviewees of Bangladesh were asked about the current film categories of Bangladesh. Most of the interviewees noted that the existing film categories should be updated for film censorship board of Bangladesh. Even members of the film censorship board also agreed that those film categories are very necessary for the film industry. Md. Nizamul Kobir, member of the film censorship board of Bangladesh, noted that: "There are different categories of films in many countries, including our neighbor countries. We have made the draft of the national film policy. Hopefully, it will be approved very soon. After approving the national film policy, we will take an initiative for censorship certification act where the film category will be mentioned."

Another member of the film censorship board, Abdur Rahman, noted that:

"Film categories are very important for the film industry. Film categories are being adopted in the film censorship board in Bangladesh since 1977 but it is not that much updated. If we update film category, our society will be benefited. Otherwise, our society will be affected badly. For the betterment of our society it is important to categorize the film as 'child movie' for the children and 'adult movie' for the adults."

Well known film director Motin Rahman, also agreed on the necessity of film categories, but he was a bit doubtful about its proper applicability. He noted that: "It is better to have a film category in our country. When category will exist, if anyone wants to produce an adult film then it should be ensured that only adults will watch that. As we are living in a Muslim country there is a matter of religions. If the films will be categorized regarding this, in that case it is not known to me that how much we will be benefited because mostly the prohibited things are always attractive for the mass people."

All the interviewees of Bangladesh agreed that film categories need to be updated for Bangladesh. Bangladesh is practicing current film categories since 1977. It is too back dated and all the interviewees agreed that Bangladesh should adopt a new film categorizing. Therefore, the researcher seems that Bangladesh should adopt new categories like Malaysia.

\section{CONCLUSION}

If you Malaysia and Bangladesh share the existence of a majority Muslims population with the Malaysian population being more pronounced in her multi-ethnic, multi-religion and multi-culture. Both countries have put in place a statutory regulatory body in approving distribution, censoring and rating films.

People in the film industry in both countries accepted the need for film rating as guidance for individuals and parents in choosing film viewing. However, their disagreement with the current system is the amount of 
restrictions still being imposed for the " 18 " rating. Perhaps more leeway should be given to the content of the film in the "18" rating particularly thematic and socio-political content of the films.

For Bangladesh, the limited categories of only " $U$ " and " $\mathrm{A}$ " may require expansion of the categories. If we consider the views from Malaysia, children may be categorised between primary school children and secondary school children with different developmental stage. Thus, at least Bangladesh could add another rating of P13.

\section{REFERENCES}

1. Austin BA. Rating the movies. Journal of Popular Film and Television. 1980 Jan 1;7(4):384-99..

2. Vaughn S. Freedom and entertainment: rating the movies in an age of new media. Cambridge University Press; 2006.

3. Millett C, Glantz SA. Assigning an '18'rating to movies with tobacco imagery is essential to reduce youth smoking.

4. Austin BA. The influence of the MPAA's film-rating system on motion picture attendance: A pilot study. The Journal of Psychology. 1980 Sep 1;106(1):91-9.

5. Friedman JM. The motion picture rating system of 1968 : A constitutional analysis of self-regulation by the film industry. Columbia Law Review. 1973 Feb 1;73(2):185240.

6. Funk JB, Flores G, Buchman DD, Germann JN. Rating electronic games: Violence is in the eye of the beholder. Youth \& Society. 1999 Mar;30(3):283-312.

7. Gross JJ, Levenson RW. Hiding feelings: the acute effects of inhibiting negative and positive emotion. Journal of abnormal psychology. 1997 Feb;106(1):95.

8. Guan ST. Film censorship in the Asia-pacific region: Malaysia, Hong Kong and Australia compared. Routledge; 2013 Apr 2.

9. Penn DL, Chamberlin C, Mueser KT. The effects of a documentary film about schizophrenia on psychiatric stigma. Schizophrenia bulletin. 2003 Jan 1;29(2):383-91.

10. Weinraub B. Loosening a Strict Film Rating for 'South Park'. New York Times. 1999.

11. Islam MZ. FILM RATING: A COMPARATIVE ANALYSIS IN MALAYSIA AND BANGLADESH. Asia Proceedings of Social Sciences. 2019 Apr 17;4(1):7-9.

\section{AUTHORS PROFILE}

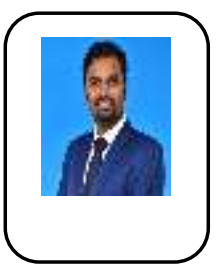

Dr. Md. Zahidul Islam has completed Ph.D, at the Ahmad Ibrahim Kulliyyah (faculty) of Laws, International Islamic University Malaysia (IIUM). $\mathrm{He}$ has achieved valuable experience in research work. Based on research evaluations, he was honored the IIUM Postgraduate Niche Area Scholarship (2013/2014) and President Scholarship (2014/2015) The author has written articles on issues on Human Rights and media law in local and international journals. He has also attended several local and international Conferences. He worked as a lecturer at the Kulliyyah (Faculty) of Shari'ah and Laws, Islamic University of Maldives. Currently, He is working as an assistant professor at the Civil Law Department, Ahmad Ibrahim Kulliyyah (Faculty) of Laws (AIKOL), International Islamic University Malaysia (IIUM). He can be contacted at: zahidul@iium.edu.my.

Md. Mashiur Rahman has completed Masters of Social Science (Social Work) at Shahjalal University of Science and Technology (SUST), Bangladesh. He received his Bachelor of Social Science (Honors) from the same instirution in Bangladesh. He has achieved valuable experience in research work and educational training as a Bangladesh Civil Service Cadre officer. As a author, he has written articles on issues- Education, Social Development and Human Rights in local and international journals. He has also attended several Conferences. Currently, $\mathrm{He}$ is working as assistant professor at Bhawal Badre Alam Government College, Gazipur under Bangladesh Civil Service (Education Cadre). Email: mashiur18gmail.com 